\title{
Detection of infectious hypodermal and hematopoietic necrosis virus (IHHNV) in Litopenaeus vannamei by ramification amplification assay
}

\author{
Ping-Hua Teng ${ }^{1,2}$, Pei-Yu Lee ${ }^{3}$, Fu-Chun Lee ${ }^{2}$, Hung-Wen Chien ${ }^{2}$, Man-Shu Chen ${ }^{2}$, \\ Ping-Feng Sung ${ }^{2}$, Chen $\mathrm{Su}^{2}$, Bor-Rung $\mathrm{Ou}^{1, *}$ \\ ${ }^{1}$ Department of Animal Science and Biotechnology, Tunghai University, Taichung 40704, Taiwan, ROC \\ ${ }^{2}$ Farming IntelliGene Technical Corporation, Taichung 40755, Taiwan, ROC \\ ${ }^{3}$ Institute of Medical Biotechnology, Central Taiwan University of Science and Technology, Taichung 406, Taiwan, ROC
}

\begin{abstract}
Infectious hypodermal and hematopoietic necrosis virus (IHHNV) is a single-stranded DNA virus that causes developmental and growth abnormalities in Pacific white shrimp Litopenaeus vannamei (also known as Penaeus vannamei). Nucleic acid based methods such as in situ hybridization (ISH) and PCR have been commonly used for IHHNV detection. Ramification amplification (RAM), an isothermal nucleic acid amplification approach, was used in this study to detect IHHNV in L. vannamei. RAM offers many advantages over PCR, including simple procedures and short detection time, and is labor-saving and cost-effective. RAM exponentially amplifies a circular oligonucleotide amplicon (C probe) after a target-specific ligation step through sequential primer extension and strand displacement processes. The conditions of an IHHNV RAM assay were optimized using artificial templates and targets prior to application. Using DNA of IHHNV-infected L. vannamei as targets, results revealed that RAM amplified target DNA with similar sensitivity as PCR. RAM offers competitive levels of speed, simplicity and sensitivity among various pathogen diagnostic methods.
\end{abstract}

KEY WORDS: IHHNV · Litopenaeus vannamei · Ramification amplification · Isothermal amplification

\section{INTRODUCTION}

Infectious hypodermal and hematopoietic necrosis virus (IHHNV) was first identified in 1981 to be the cause of mass mortality in blue shrimp Litopenaeus stylirostris (also known as Penaeus stylirostris) (Lightner et al. 1983a,b). In Pacific white shrimp Litopenaeus vannamei (also known as Penaeus vannamei), IHHNV causes growth reduction and runt deformity syndrome (RDS) rather than high rates of mortality (Kalagayan et al. 1991). The economic loss caused by IHHNV infection in the USA from 1981 to 2001 was estimated to reach 0.5 to 1.0 billion \$US (Lightner 2003).

According to morphological and genetic characteristics, IHHNV is classified as a member of the Parvoviridae family (Bonami et al. 1990, Mari et al. 1993) and is closely related to densoviruses of the genus Brevidensovirus (Shike et al. 2000). IHHNV has a non- enveloped icosahedral particle $22 \mathrm{~nm}$ in diameter, which contains linear $4.1 \mathrm{~kb}$ single-stranded DNA (Berns et al. 1995). Analysis of the genomic sequences of IHHNV collected in the USA between 1982 and 1997 showed that there was a low level of variation among these isolates (Tang \& Lightner 2002).

To avoid cross-species infection by IHHNV, routine surveillance of IHHNV is crucial for shrimp farmers and quarantine services. Recently, several PCR methods were developed for IHHNV detection in shrimp tissues (Lightner et al. 1994, Poulos et al. 1995) as well as in culture system detritus, mud and seawater (Glover et al. 1995). Quantitative real-time PCR IHHNV detection kits have also been developed (Dhar et al. 2001, Tang \& Lightner 2001). Although PCR-based methods have been commonly accepted in laboratories, they are generally not suitable for on-site pathogen detection due to their high cost and technical requirements. 
Ramification amplification (RAM), a novel DNA amplification method, was first described in 1998 by Zhang et al. (1998). RAM is an isothermal amplification method that utilizes a circularizable oligodeoxyribonucleotide probe (C probe) as an amplifiable target. The $\mathrm{C}$ probe is a synthetic oligonucleotide with a sequence complementary to the specific target sequence. Upon hybridization to the target DNA, the 5' and 3' ends of the $\mathrm{C}$ probe are drawn together and can be ligated to form a closed circular molecule (Nilsson et al. 1994). Under isothermal condition, the circular $\mathrm{C}$ probe is subsequently amplified with a pair of $\mathrm{C}$ probe-specific primers, driven by Bst DNA polymerase with high strand-displacement activity. This amplification is also named hyperbranched rolling circle amplification or cascade rolling circle amplification.

After RAM was first demonstrated by Zhang et al. (1998), it became widely applied to DNA-, RNA- or protein-based diagnosis and single nucleotide polymorphism analysis (Barany 1991, Tyagi et al. 1996, Lizardi et al. 1998, Thomas et al. 1999, Schweitzer et al. 2000, Wiltshire et al. 2000). Other isothermal amplification methods, such as loop-mediated isothermal amplification (LAMP), have also been reported to detect targets at the fentogram range under isothermal conditions (Kono et al. 2004). However, RAM includes a ligation step that offers better specificity over other isothermal amplification strategies (Zhang et al. 1998). If mismatch occurs at the ends of the $C$ probes at the annealing stage, the ligation step in RAM would not proceed to allow the subsequent signal amplification step. Furthermore, RAM could yield more than $10^{6}$ copies of amplicons within $1 \mathrm{~h}$ from 20 copies of $\mathrm{C}$ probes (Zhang et al. 1998), and shows a level of amplification efficiency competitive with that of other amplification methods such as PCR and LAMP.

In this study, an IHHNV RAM method was established and evaluated for the detection of IHHNV in Litopenaeus vannamei. By modifying the amplification conditions, an IHHNV RAM detection system was set up and further developed into a point-of-operation diagnostic kit.

\section{MATERIALS AND METHODS}

Sample preparation and DNA extraction. Shrimp Litopenaeus vannamei samples were collected from shrimp farms in Taiwan. For DNA extraction, 1 gill (about $20 \mathrm{mg}$ ) was ground thoroughly in $500 \mu \mathrm{l}$ of Lysis Buffer (Farming IntelliGene). After incubation at $95^{\circ} \mathrm{C}$ for $10 \mathrm{~min}$, samples were centrifuged at $12000 \times g$ for $10 \mathrm{~min}$ to remove the cell debris. Subsequently, $200 \mu \mathrm{l}$ of supernatant was precipitated with $400 \mu$ of $95 \%$ ethanol and centrifuged at 12000 $\times g$ for $5 \mathrm{~min}$. The pellets were air-dried and stored at $-20^{\circ} \mathrm{C}$.

Circular $\mathbf{C}$ probe preparation. The sequences of the $\mathrm{C}$ probe and probe $\mathrm{IHH}-3227$ are listed in Table 1. To prepare circularized $\mathrm{C}$ probe, $10^{11}$ copies of the $106 \mathrm{bp} \mathrm{C}$ probe were incubated with excess amounts of the $54 \mathrm{bp}$ IHH-3227 oligonucleotide at $55^{\circ} \mathrm{C}$ for $1 \mathrm{~h}$ to allow the $\mathrm{C}$ probe to anneal to IHH-3227. Subsequently, T4 DNA ligase was added and the ligation reaction was performed at $37^{\circ} \mathrm{C}$ for $30 \mathrm{~min}$. Circular $\mathrm{C}$ probes that were twisted around the IHH-3227 were purified by the GeneSpin 1-4-3 DNA extraction kit (Promega) in order to remove the salts, enzymes and linear oligonucleotides, dissolved in $1 \times \mathrm{TE}$ buffer, and stored at $-20^{\circ} \mathrm{C}$.

Coupling of biotin-labeled probes to streptavidincoated beads. Streptavidin-coated magnetic beads (Promega) were used to immobilize the biotin-labeled capture probes NCA2-b and NCA3-b (Table 1). Briefly, $0.5 \mu \mathrm{M}$ of probes were incubated with $2.5 \mathrm{mg} \mathrm{ml}^{-1}$ streptavidin-coated magnetic beads in $5 \times$ saline sodium citrate (SSC) buffer for $10 \mathrm{~min}$ at room temperature, followed by several washes in distilled water to remove unbound probes.

RAM assay. A schematic of the IHHNV RAM assay is provided in Fig. 1. Initially, $5 \mu \mathrm{l}$ of DNA extract, $10^{9}$ copies of $\mathrm{C}$ probe, and $5 \mu \mathrm{g}$ of magnetic beads coated with the IHHNV-specific probes NCA2-b/NCA3-b were allowed to hybridize in a total of $50 \mu \mathrm{l} 5 \times \mathrm{SSC}$ and $7.5 \%$ dextran sulfate at $55^{\circ} \mathrm{C}$ for $1 \mathrm{~h}$. After 2 washes with $50 \mu \mathrm{l} 0.5 \times \mathrm{SSC}$, the mixture was added to a $10 \mu \mathrm{l}$ ligation mixture containing 0.5 unit of T4 DNA ligase (Promega), incubated at $37^{\circ} \mathrm{C}$ for $10 \mathrm{~min}$ and washed twice with $50 \mu \mathrm{l} 0.5 \times \mathrm{SSC}$. Subsequently, $20 \mu \mathrm{l}$ of the

Table 1. Oligonucleotides used in IHHNV RAM assay

\begin{tabular}{ll} 
Oligonucleotide & Sequence \\
\hline C probe & 5'-GCTTCCTTAGTTGATAGTTGATT- \\
& ATTATCTGCTAACCAAGAGCAACT- \\
& ACACTCGGAATCATTAGGTTACT- \\
& GCGATTAGCACACGCATTTGCC- \\
& AATGTTACGTCG-3' \\
IHH-3227 & 5'-GACTACATAATCAACTATCAAC- \\
& TAAGGAAGCCGACGTAACATTGG- \\
& CAAAATGGA-3' \\
RAM-F & 5'-GTGTAGTTGCTCTTGGTTAGA-3' \\
RAM-R & 5'-ATTCATTAGGTTACTGCGATTAG- \\
& CACA-3' \\
NCA2-b & 5'-CCCAACTTGTGACCGTACAATC- \\
& AA-biotin-3' \\
NCA3-b & 5'-ACACTAGAAATTGGTATGGCG- \\
& GAGAA-biotin-3' \\
106BD-b & 5'-GCCAATGTTACGTCGGCTTCCT- \\
& TAGTT-biotin-3'
\end{tabular}



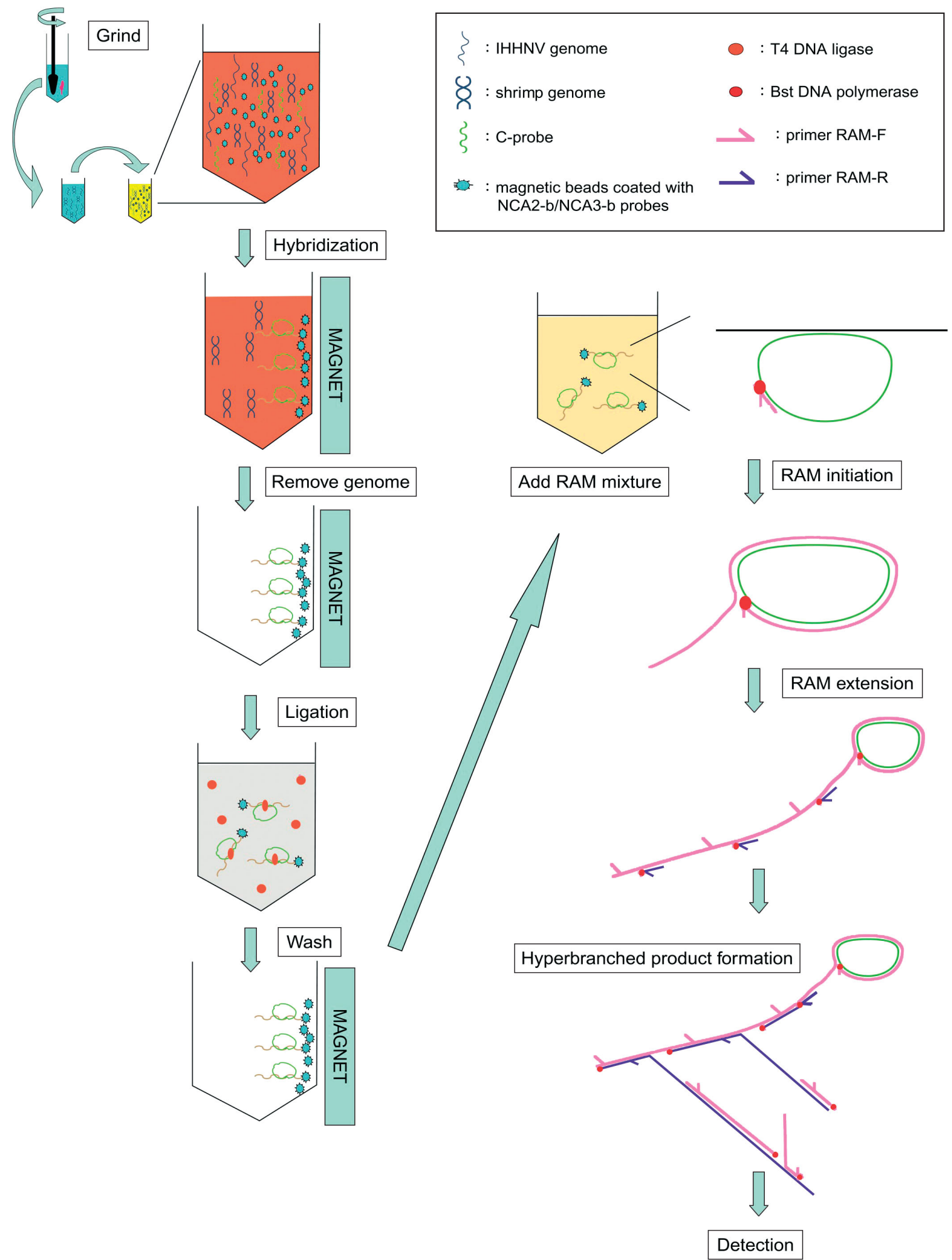

Fig. 1. Schematic IHHNV RAM assay. Samples were ground thoroughly and lysed by lysis buffer, then C probes and magnetic beads coated with capture probes were added to the lysate. The mixture containing IHHNV genome, C probe and magnetic beads coupled with capture probes was formed after hybridization. Shrimp genome and unbound C probes were removed by a washing step. Ligation of C probe ends was achieved by T4 DNA ligase. An additional washing step removed non-ligated C probes prior to addition of RAM reaction mixture and Bst DNA polymerase to the ligated complex. Numerous concatemerized hyperbranched repeats, derived from the $\mathrm{C}$ probe, were formed through DNA polymerization and strand displacement and detected by agarose gel electrophoresis or dot blot assay 
RAM mixture (300 $\mu \mathrm{M}$ dNTP, 20 mM Tris-Cl [pH 8.8], $10 \mathrm{mM} \mathrm{KCl}, 10 \mathrm{mM}\left(\mathrm{NH}_{4}\right)_{2} \mathrm{SO}_{4}, 3 \mathrm{mM} \mathrm{MgSO}{ }_{4}, 0.1 \%$ Triton X-100), $1.2 \mu \mathrm{M}$ of each primer and 6.4 units of Bst DNA polymerase (New England Biolabs) were added. The resulting mixture was incubated at $63^{\circ} \mathrm{C}$ for $60 \mathrm{~min}$, followed by inactivation of the enzymes at $80^{\circ} \mathrm{C}$ for $10 \mathrm{~min}$. The amplified products were analyzed by electrophoresis on a $2 \%$ agarose gel.

PCR for IHHNV detection. For comparative studies of the sensitivity of the RAM assay, the PCR-based IQ2000 IHHNV detection system (Farming IntelliGene) was used. The reaction conditions for the IQ2000 IHHNV detection system included 10 cycles of $94^{\circ} \mathrm{C}$ for $20 \mathrm{~s}$ and $70^{\circ} \mathrm{C}$ for $20 \mathrm{~s} ; 35$ cycles of $94^{\circ} \mathrm{C}$ for $20 \mathrm{~s}, 56^{\circ} \mathrm{C}$ for $20 \mathrm{~s}$ and $72^{\circ} \mathrm{C}$ for $30 \mathrm{~s}$, followed by an incubation at $72^{\circ} \mathrm{C}$ for $30 \mathrm{~s}$ and $20^{\circ} \mathrm{C}$ for $30 \mathrm{~s}$. After the reaction was completed, samples were analyzed by electrophoresis on a $2 \%$ agarose gel. To clarify the specificity of the primer sets of IHHNV RAM, samples were prepared from white spot syndrome virus (WSSV)-infected shrimps, and the PCR-based IQ2000 WSSV detection system (Farming IntelliGene) was used. This system was a nested PCR that included 2 steps. The first run was 5 cycles of $94^{\circ} \mathrm{C}$ for $30 \mathrm{~s}, 62^{\circ} \mathrm{C}$ for $30 \mathrm{~s}$ and $72^{\circ} \mathrm{C}$ for $30 \mathrm{~s}$, followed by 15 cycles of $94^{\circ} \mathrm{C}$ for $15 \mathrm{sec}, 62^{\circ} \mathrm{C}$ for $15 \mathrm{~s}$ and $72^{\circ} \mathrm{C}$ for $20 \mathrm{~s}$. The nested run was 25 cycles of $94^{\circ} \mathrm{C}$ for $20 \mathrm{~s}, 62^{\circ} \mathrm{C}$ for $20 \mathrm{~s}$ and $72^{\circ} \mathrm{C}$ for $30 \mathrm{~s}$ followed by incubation at $72^{\circ} \mathrm{C}$ for $30 \mathrm{~s}$ and $20^{\circ} \mathrm{C}$ for $30 \mathrm{~s}$. After the reaction was completed, the samples were analyzed by electrophoresis on a $2 \%$ agarose gel.

Dot blot assay. RAM products $(1 \mu \mathrm{l})$ were spotted onto a nylon membrane (Millipore) and fixed by UV cross-linking at $0.12 \mathrm{~J} \mathrm{~cm}^{-2}$ in a UV Crosslinker Box (Spectroline). The membrane was then hybridized with the biotin-labeled probe 106BD-b (Table 1) at $63^{\circ} \mathrm{C}$ in hybridization buffer $(5 \times \mathrm{SSC})$ for $1 \mathrm{~h}$, washed twice in wash buffer $(1 \times \mathrm{SSC})$, incubated with $10 \mu \mathrm{g} \mathrm{ml}^{-1}$ streptavidin-alkaline phosphatase conjugate (Promega) in blocking buffer $(100 \mathrm{mM}$ Tris- $\mathrm{Cl} \mathrm{pH}$ 8.0, $150 \mathrm{mM} \mathrm{NaCl}, 0.3 \%$ Tween-20) at $25^{\circ} \mathrm{C}$ for $10 \mathrm{~min}$ and washed twice in $1 \times \mathrm{SSC}$. Nitroblue tetrazolium/5bromo-4-chloro-3-indolyl phosphate (NBT/BCIP) substrate (Promega) diluted 100-fold in alkaline phosphatase buffer (100 mM Tris-Cl pH 9.0, $150 \mathrm{mM} \mathrm{NaCl}$, $5 \mathrm{mM} \mathrm{MgCl}_{2}$ ) was added to the membrane and incubated at $25^{\circ} \mathrm{C}$ for $10 \mathrm{~min}$.

\section{RESULTS}

\section{Optimization of IHHNV RAM assay}

In the RAM assay, the Bst DNA polymerase plays an important role in the production of the ramification products. Bst DNA polymerase, a thermo-stable DNA polymerase with high strand displacement activities, was first isolated from Bacillus stearothermophilus and used for DNA sequence analysis (Mead et al. 1991). Magnesium ion $\left(\mathrm{Mg}^{2+}\right)$, a known cofactor of Bst DNA polymerase, is crucial to the activity of the enzyme. The effect of $\mathrm{Mg}^{2+}$ concentration on a Bst DNA polymerasemediated ramification reaction was investigated by using the circularized $\mathrm{C}$ probes as standards. The optimal concentration of $\mathrm{Mg}^{2+}$ required to detect $10^{3}$ copies of template in the reaction was determined to be $3 \mathrm{mM}$ (data not shown). Other components such as dimethyl sulfoxide (DMSO) and formamide had been reported to enhance the specificity of the ramification reaction (Cheng et al. 1994, Varadaraj \& Skinner 1994). However, no significant difference was detected regardless of DMSO or formamide addition in the test reaction (data not shown). The final RAM buffer contained $20 \mathrm{mM}$ Tris- $\mathrm{Cl}$ (pH 8.8), $10 \mathrm{mM} \mathrm{KCl}, 10 \mathrm{mM}\left(\mathrm{NH}_{4}\right)_{2} \mathrm{SO}_{4}$, $3 \mathrm{mM} \mathrm{MgSO}_{4}$ and $0.1 \%$ Triton X-100.

To estimate the sensitivity of the ramification step alone without involving the ligation step, serial 10-fold dilutions ( $10^{1}$ to $10^{7}$ copies) of circularized C probe (see 'Materials and methods') were used as templates. The sequences of oligonucleotides used in this study are listed in Table 1. The DNA ladders of the hyperbranched RAM products were analyzed by electrophoresis on a $2 \%$ agarose gel. RAM products were obtained with $10^{7}$ down to $10^{1}$ copies of the circular targets (Fig. 2). This result revealed that the ramification step achieved high degrees of sensitivity.

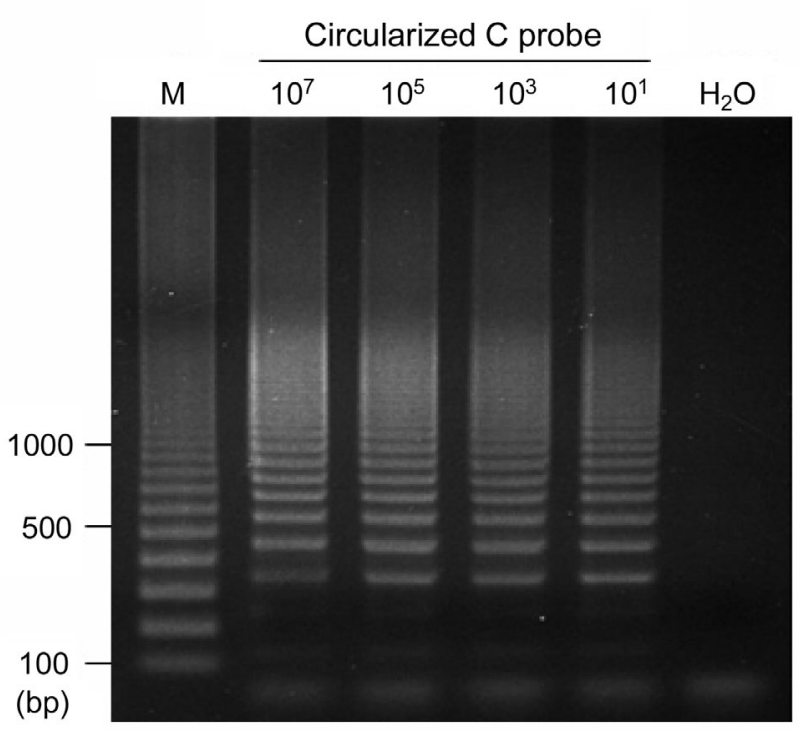

Fig. 2. Detection of circularized $\mathrm{C}$ probe amplified by $B s t$ DNA polymerase. Variable numbers of copies $\left(10^{7}, 10^{5}, 10^{3}\right.$, $10^{1}$ ) of circularized $\mathrm{C}$ probe were used. The RAM reaction, using RAM-F and RAM-R primers, was performed at $63^{\circ} \mathrm{C}$ for $60 \mathrm{~min}$. Amplified products were detected by electrophoresis on a 2\% agarose gel. M: 100 bp DNA ladders; $\mathrm{H}_{2} \mathrm{O}$ : no circularized $\mathrm{C}$ probe added 


\section{IHHNV RAM assay targeting an artificial oligonucleotide}

Based on the published IHHNV genome sequence (GenBank accession number AY355308), the oligonucleotide sequence of IHH-3227 was designed to serve as an artificial template to set up the IHHNV RAM assay. IHH-3227 $\left(10^{1}, 10^{3}\right.$ and $\left.10^{5}\right)$ was used as the initial template and $10^{9}$ copies of the linear $\mathrm{C}$ probe were added to the IHHNV RAM reaction. RAM products were analyzed by electrophoresis. The results showed that as few as $10^{1}$ copies of the IHH-3227 target led to the production of expected IHHNV RAM products (Fig. 3) and demonstrated the feasibility and sensitivity of the IHHNV RAM reaction.

\section{Sensitivity and specificity of IHHNV RAM assay compared with IHHNV PCR}

The sensitivity of the IHHNV RAM assay was evaluated by using the IQ2000 IHHNV diagnostic system. The IQ2000 diagnostic kit is a PCR-based IHHNV detection system with high sensitivity and specificity. Serial 10 -fold dilutions $\left(10^{1}, 10^{2}, 10^{3}\right.$ or $\left.10^{4}\right)$ of DNA

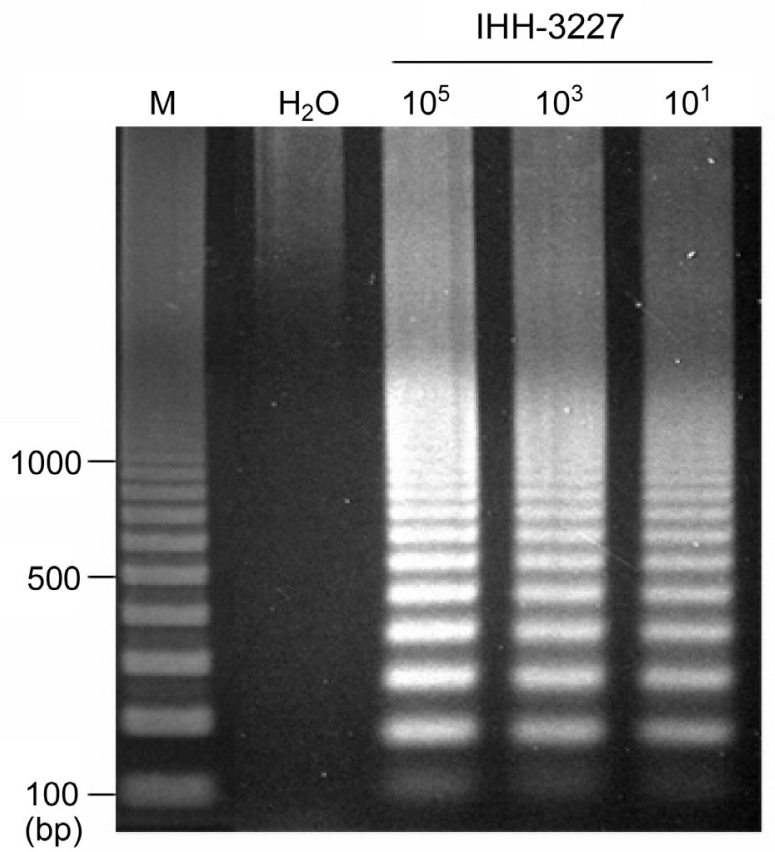

Fig. 3. Detection of a synthetic oligonucleotide target by IHHNV RAM assay. Variable numbers of copies $\left(10^{5}, 10^{3}, 10^{1}\right.$, 0 ) of IHH-3227 and $10^{9}$ copies of linear $\mathrm{C}$ probe were added in each test. After initial hybridization and ligation steps, ramification amplification using RAM-F and RAM-R primers was performed (see 'Materials and methods'). RAM products were detected by electrophoresis on a $2 \%$ agarose gel. M: 100 bp DNA ladders; $\mathrm{H}_{2} \mathrm{O}$ : no IHH-3227 added extracted from Litopenaeus vannamei were examined. Products were observed with a DNA sample diluted as much as $10^{4}$-fold in both the RAM and PCR reactions (Fig. 4A,B). RAM products were analyzed by dot blot assay to confirm that ladders were $\mathrm{C}$ probe-dependent amplicons (Fig. 4C). To clarify the specificity of this primer set, 2 WSSV-infected shrimps (Fig. 5A), 2 IHHNV-infected shrimps (Fig. 5B) and 2 negative samples were assayed by IHHNV RAM. Only IHHNVinfected samples showed positive results after IHHNV RAM assay (Fig. 5C).
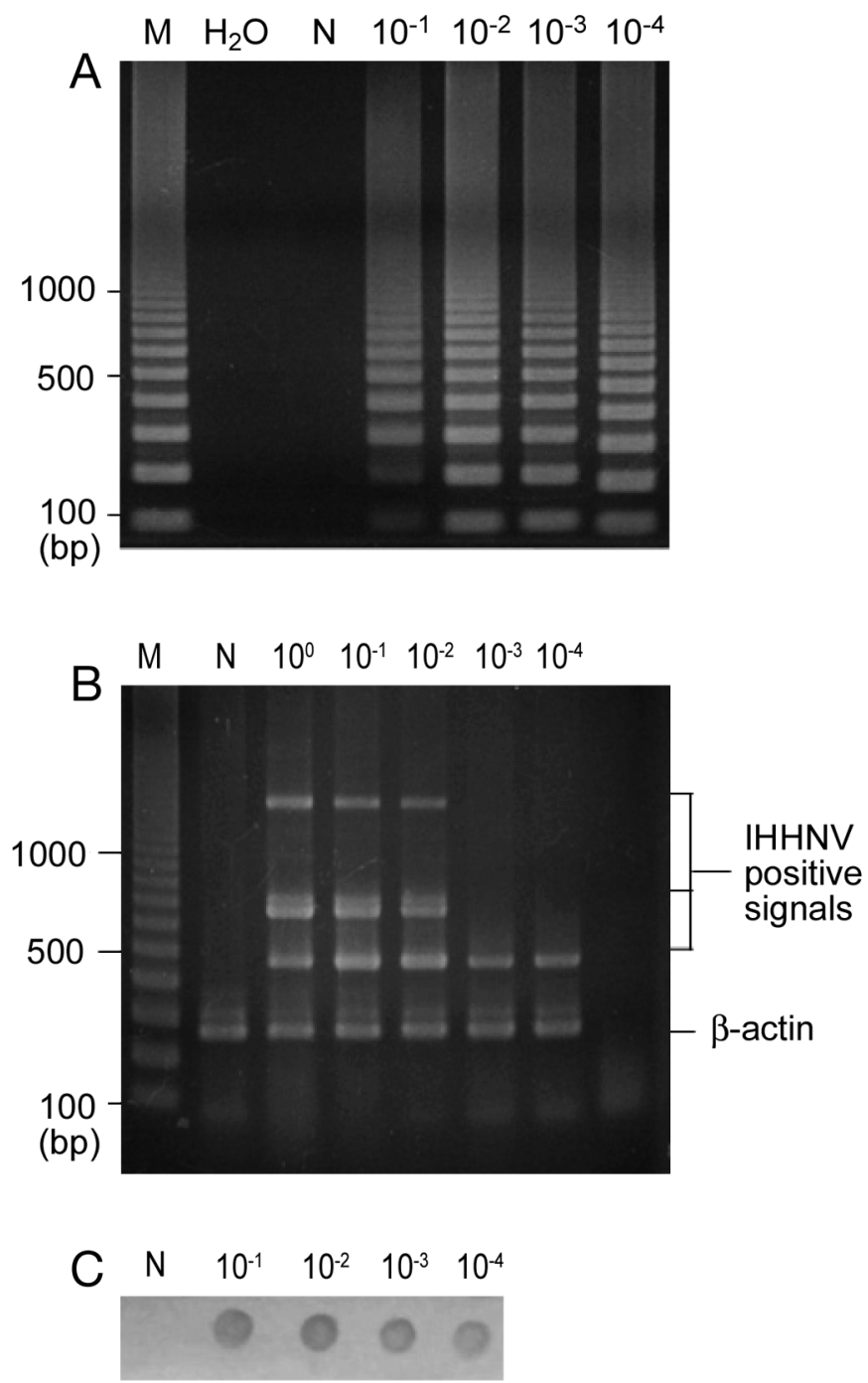

Fig. 4. Comparison of sensitivity between IHHNV RAM assay and IQ2000 IHHNV detection system. DNA extracts of various dilutions $\left(10^{0}, 10^{-1}, 10^{-2}, 10^{-3}, 10^{-4}\right)$ were prepared from Litopenaeus vannamei and amplified by (A) IHHNV RAM assay or (B) IQ2000 IHHNV detection system. Products were analyzed by electrophoresis on a $2 \%$ agarose gel. (C) IHHNV RAM products were further confirmed by dot blotting analysis. M: 100 bp DNA ladders; $\mathrm{H}_{2} \mathrm{O}$ : no DNA extract added; $\mathrm{N}$ : negative control (yeast tRNA) 

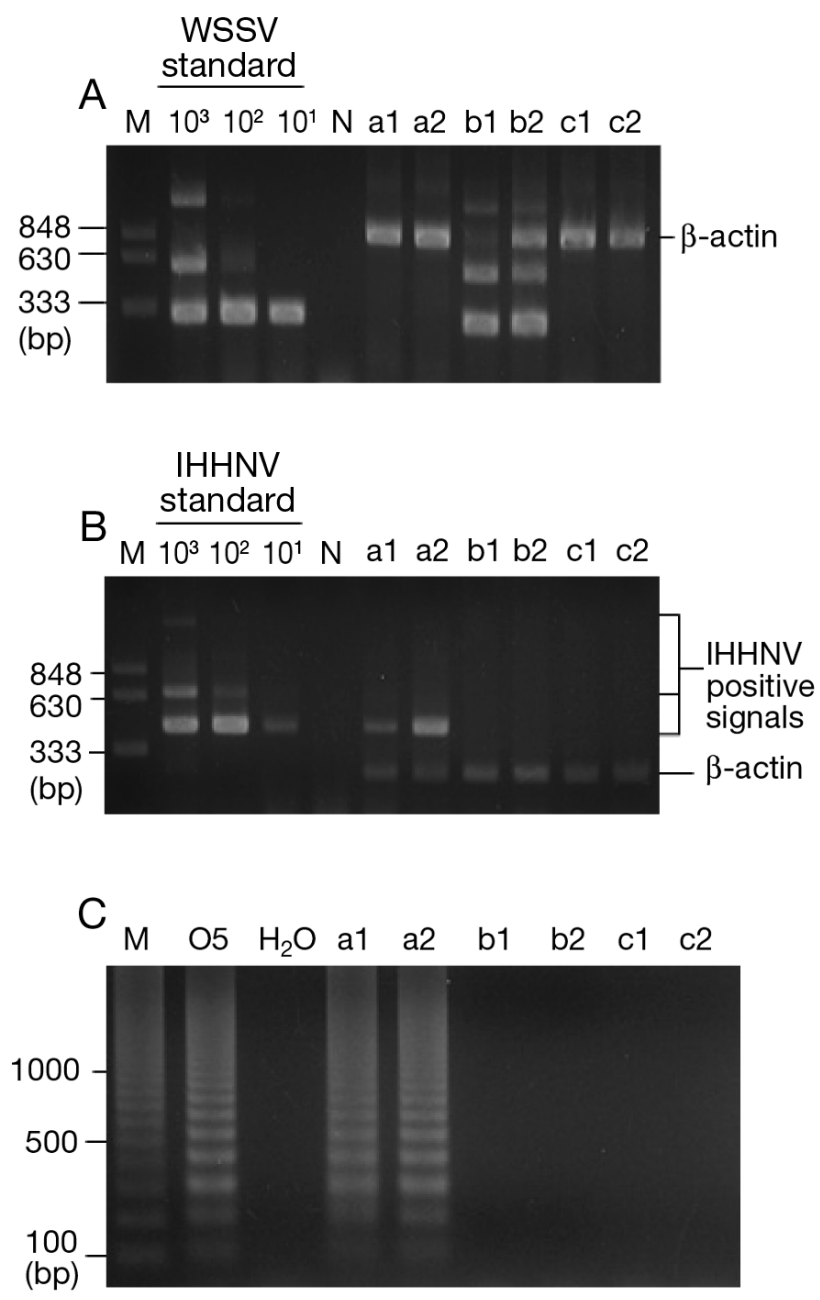

Fig. 5. Specificity of IHHNV RAM assay. Samples were prepared from Litopenaeus vannamei and assayed by (A) IQ2000 WSSV detection system, (B) IQ2000 IHHNV detection system and (C) IHHNV RAM assay. The standard group contained various plasmid copies containing either WSSV or IHHNV partial sequences; a1 and a2 samples were from IHHNVinfected shrimps; b1 and b2 samples were from WSSVinfected shrimps; $\mathrm{c} 1$ and $\mathrm{c} 2$ samples were from WSSV- and IHHNV-negative shrimps. Products were analyzed by electrophoresis on a $2 \%$ agarose gel. M: DNA ladders; $\mathrm{H}_{2} \mathrm{O}$ : no DNA added; O5: $10^{5}$ copies of circularized C probe alone; $\mathrm{N}$ : negative control (yeast tRNA)

\section{Sensitivity of IHHNV RAM assay using shrimp samples}

To further evaluate the sensitivity of the IHHNV RAM assay, shrimp samples were collected from shrimp culture ponds and diagnosed using the IQ2000 IHHNV detection system. Out of 4 test samples, 2 samples (\#27 and \#13) were 10-fold serially diluted and determined by the IQ2000 IHHNV PCR method to be lightly infected (Fig. 6A), whereas the
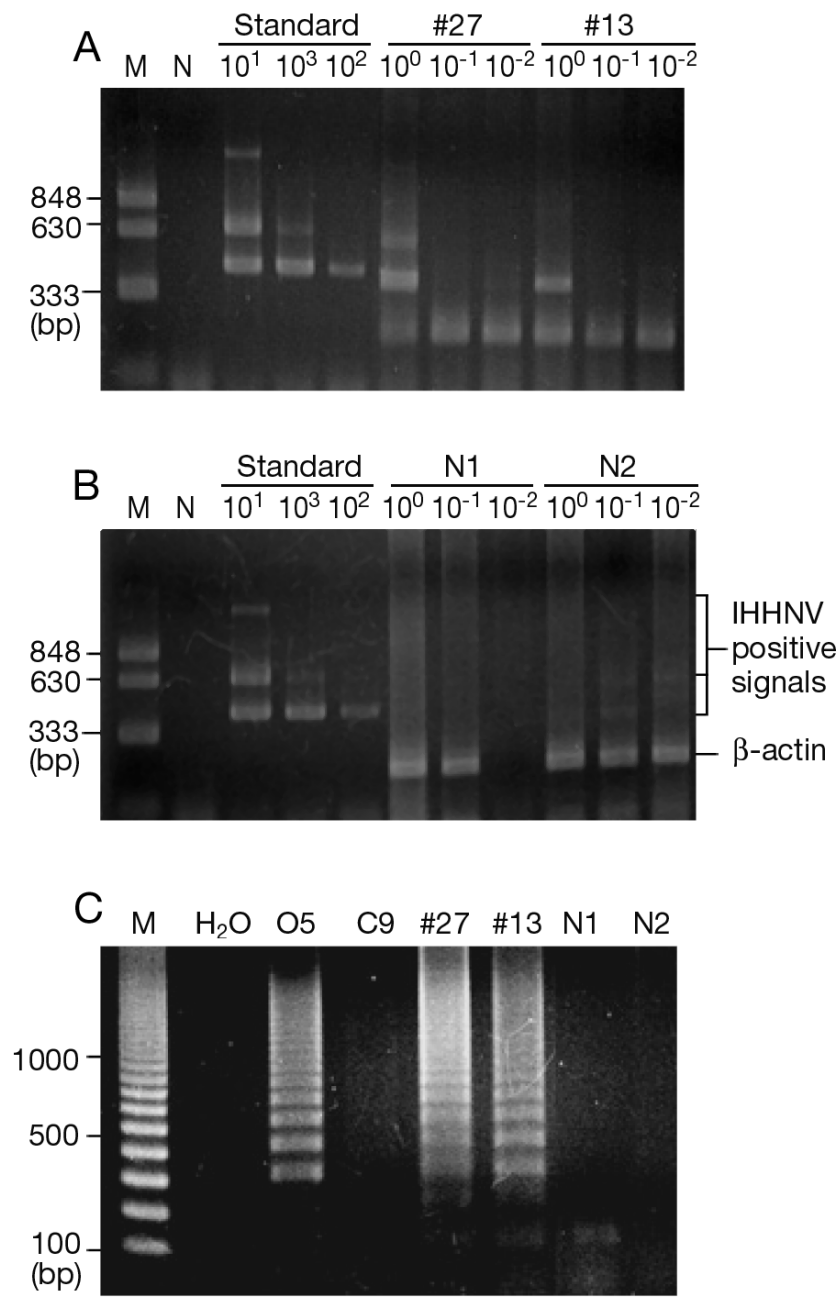

Fig. 6. Detection of IHHNV infection from farmed Litopenaeus vannamei samples by RAM assay. (A) IHHNV-infected L. vannamei DNA samples were diagnosed by IQ2000 IHHNV detection system. The standard group contained variable numbers of plasmid copies $\left(10^{4}, 10^{3}, 10^{2}\right)$ containing IHHNV partial sequences; \#27 and \#13 groups were DNA samples prepared from $L$. vannamei at various dilutions $\left(10^{0}\right.$, $10^{-1}$ or $10^{-2}$ ). (B) IHHNV-negative $L$. vannamei DNA samples were analyzed by IQ2000 IHHNV detection system. M: DNA marker; N: negative control without DNA added. N1 and N2 groups were DNA samples prepared from $L$. vannamei at various dilutions $\left(10^{0}, 10^{-1}\right.$ or $\left.10^{-2}\right)$. (C) The same samples used in (A) were subjected to IHHNV RAM assay. RAM products were analyzed by electrophoresis on a $2 \%$ agarose gel. M: 100 bp DNA ladders. $\mathrm{H}_{2} \mathrm{O}$ : No DNA added; N: negative control (yeast tRNA); O5: $10^{5}$ copies of circularized $\mathrm{C}$ probe alone; C9: $10^{9}$ copies of linear $\mathrm{C}$ probe alone

other 2 samples (N1 and N2) were assessed by the same method to be IHHNV-negative (Fig. 6B). A similar degree of sensitivity was obtained with the IHHNV RAM assay (Fig. 6C). These results indicate that RAM offers a feasible method for sensitive detection of IHHNV in the field. 


\section{DISCUSSION}

In this study, a RAM assay was developed as a simple and sensitive IHHNV detection method. Optimal conditions for the ramification step were established in order to generate detectable products from $10^{1}$ copies of an artificially generated circular $\mathrm{C}$ probe and its specific primers (Fig. 2). Subsequently, an IHHNV-specific RAM assay was developed after coupling with a target-specific ligation step using a synthetic linear target. Detectable products were observed from as few as $10^{1}$ copies of the artificial target (Fig. 3). The sensitivity of the IHHNV RAM assay was similar to that of the IQ2000 IHHNV detection system when DNA extracted from IHHNV-infected Litopenaeus vannamei was used as targets (Figs. $4 \& 6$ ).

The selection of DNA polymerases is important for successful RAM reaction. The hyperbranched DNA products are formed in RAM reaction as a result of the polymerization, strand displacement and high processing activities of DNA polymerases (Fig. 1). However, when the $\mathrm{C}$ probes hybridize onto the targets, the topological constraint at the hybridized area seems to interfere with subsequent strand extension by some DNA polymerases (Baner et al. 1998). The Klenow fragment of E. coli DNA polymerase I cannot pass through the hybridized area between the $\mathrm{C}$ probe and the target (Baner et al. 1998). Although the phi 29 DNA polymerase, isolated from Bacillus subtilis bacteriophage phi 29, was reported to possess the ability to efficiently elongate long single-stranded DNA (Lizardi et al. 1998, Zhang et al. 2001a), the sensitivity of RAM achieved by the phi 29 DNA polymerase was 1000-fold lower than that of the Bst DNA polymerase, possibly owing to low intrinsic strand displacement activity (Zhang et al. 2001a). Therefore, the Bst DNA polymerase appears to be the optimal choice for now.

The Bst DNA polymerase, which possesses high strand displacement activity and lacks 5'-3' exonuclease activity, was used to amplify the $\mathrm{C}$ probe signal in this study. To optimize reaction conditions for the Bst DNA polymerase-mediated ramification step, the circularized $\mathrm{C}$ probes were used as templates to bypass the ligation step. Without available information on the optimal concentrations of divalent cations for the Bst DNA polymerase, different concentrations of $\mathrm{Mg}^{2+}$ were added to the commercial standard buffer to attain optimal RAM sensitivity. The concentrations of $\mathrm{Mg}^{2+}$ proved to be critical at this step. A $3 \mathrm{mM}$ concentration of $\mathrm{Mg}^{2+}$ generated a 1000-fold increase in RAM sensitivity compared with a 2 or $4 \mathrm{mM}$ concentration (data not shown). The suitable range of $\mathrm{Mg}^{2+}$ concentrations is thus narrow. Although magnesium ions were reported to be superior to manganese and calcium ions in mediating the activities of DNA polymerase (Chien et al. 1976), replacement of magnesium ions by other divalent ions has not yet been excluded.

Since DMSO and L-proline were reported to facilitate DNA elongation step and stabilize the polymerase-template complex (Zhang et al. 2001b) for DNA replication by Bst DNA polymerase, these components were tested separately in the RAM reaction mixture. However, no significant enhancement of RAM sensitivity was observed (data not shown). The effect of buffer components may be dependent on target DNA characteristics, such as DNA secondary structure or the inclusion of GC-rich regions.

The ligation reaction is another critical step of RAM assay. Without a successful ligation step, the $\mathrm{C}$ probes would not be circularized to allow RAM to proceed. In this study, T4 DNA ligase was used to link the junction formed after the $\mathrm{C}$ probes had perfectly annealed on the targets. T4 DNA ligase is an ATP-dependent DNA ligase that ligates DNA probes onto a DNA or RNA template (Nilsson et al. 2000, 2001). The quantity of circularized probes formed on targets is one of the key factors that determines the success of the RAM reaction. However, if the amounts of nonspecific circularized $\mathrm{C}$ probe products exceeded detection limits, false-positive results would be observed. Kuhn \& Frank-Kamenetskii (2005) recently reported that non-template ligation of DNA by T4 DNA ligase generated very low yield that resulted in a background signal or false-positives. The fidelity of T4 DNA ligase is 1 to 2 orders of magnitude greater than that of thermostable ligases from thermophilic bacteria (Luo et al. 1996, Tong et al. 1999). Therefore, thermostable DNA ligases such as Thermus thermophilus (Tth) ligase and Thermus aquaticus (Taq) DNA ligase may be suitable alternatives to achieve higher fidelity of the RAM reaction.

To avoid false diagnosis, the concentration of $\mathrm{C}$ probes needs to be optimized. In this study, the initial amounts of linear $\mathrm{C}$ probes $\left(10^{9}\right.$ copies) could potentially result in the formation of template-independent ligation products by T4 DNA ligase. However, prior to the ligation step, magnetic bead-based sandwich hybridization was used to capture IHHNV genome and the $\mathrm{C}$ probe through capture probes. The hybridization and washing steps prior to the ligation step should greatly reduce the amount of free $\mathrm{C}$ probes and eliminate the possibility of creating detectable amounts of false-positive products.

Many features of the IHHNV RAM assay, such as its time efficiency, simplicity and sensitivity, suggest that it is a potential platform for the diagnosis of IHHNV and other pathogens. Moreover, RAM assay is a feasible method that may allow shrimp farmers to detect 
shrimp pathogens on-site without the need for expensive thermocyclers and complex protocols.

Acknowledgements. We are grateful to Ms. J. A. Butler from Oregon State University for her critical review of this manuscript. We acknowledge a grant to B.R.O. from Farming IntelliGene, Taiwan.

\section{LITERATURE CITED}

Baner J, Nilsson M, Mendel-Hartvig M, Landegren U (1998) Signal amplification of padlock probes by rolling circle replication. Nucleic Acids Res 26:5073-5078

Barany F (1991) Genetic disease detection and DNA amplification using cloned thermostable ligase. Proc Natl Acad Sci USA 88:189-193

Berns KI, Bergoin M, Bloom M. Lederman M, Muzyczka N, Siegl G, Tal J, Tattersall P (1995) Parvoviridae: VIth report of international committee on taxonomy of viruses. Arch Virol Suppl 10:169-178

Bonami JR, Trumper B, Mari J, Nrehelin M, Lightner DV (1990) Purification and characterization of the infectious hypodermal and haematopoietic necrosis virus of penaeid shrimps. J Gen Virol 71:2657-2664

Cheng S, Fockler C, Barnes WM, Higuchi R (1994) Effective amplification of long targets from cloned inserts and human genomic DNA. Proc Natl Acad Sci USA 91: 5695-5699

Chien A, Edgar DB, Trela JM (1976) Deoxyribonucleic acid polymerase from the extreme thermophile Thermus aquaticus. J Bacteriol 127:1550-1557

Dhar AK, Roux MM, Klimpel KR (2001) Detection and quantification of infectious hypodermal and hematopoietic necrosis virus (IHHNV) and white spot virus (WSV) of shrimp by real-time quantitative PCR and SYBR chemistry. J Clin Microbiol 39:2835-2845

Glover KL, Nunan LM, Lightner DV (1995) Measurement using polymerase chain reaction (PCR) of the survival of infectious hypodermal and hematopoietic necrosis virus (IHHNV) subjected to shrimp culture disinfection techniques. In: Browdy CL, Hopkins JS (eds) Swimming through troubled water. Proc Spec Sess Shrimp Farming, Aquaculture '95. World Aquaculture Society, Baton Rouge, LA, p 239 (Abstract)

Kalagayan H, Godin D, Kanna R, Hagino G, Sweeney J, Wyban J, Brock J (1991) IHHN virus as an etiological factor in runt-deformity syndrome (RDS) of juvenile Penaeus vannamei cultured in Hawaii. J World Aquac Soc 22: 235-243

Kono T, Savan R, Sakai M, Itami T (2004) Detection of white spot syndrome virus in shrimp by loop-mediate isothermal amplification. J Virol Methods 115:59-65

Kuhn H, Frank-Kamenetskii MD (2005) Template-independent ligation of single-stranded DNA by T4 DNA ligase. FEBS J 272:5991-6000

Lightner DV (2003) Exclusion of specific pathogens for disease prevention in a penaeid shrimp biosecurity program. In: Lee CS, O'Bryen PJ (eds) Biosecurity in aquaculture production systems: exclusion of pathogens and other undesirables. World Aquaculture Society, Baton Rouge, LA, p 81-116

Lightner DV, Redman RM, Bell TA (1983a) Infectious hypodermal and hematopoietic necrosis, a newly recognized virus disease of penaeid shrimp. J Invertebr Pathol 42: 62-70

Lightner DV, Redman RM, Bell TA, Brock JA (1983b) Detection of IHHN virus in Penaeus stylirostris and P. vannamei imported into Hawaii. J World Maric Soc 14:221-225

Lightner DV, Poulos BT, Bruce L, Redman RM, Nunan L, Pantoja C, Mari J, Bonami JR (1994) Development and application of genomic probes for use as diagnostic and research reagents for the penaeid shrimp parvoviruses IHHNV and HPV, and the baculoviruses MBV and BP. In: Peterson MS (ed) US marine shrimp farming program 10th anniversary review. Gulf Coast Research Laboratory Spec Publ, Gulf Research Reports No. 1, Ocean Springs, MS, p 59-85

Lizardi PM, Huang X, Zhu Z, Bray-Ward P, Thomas DC, Ward DC (1998) Mutation detection and single molecule counting using isothermal rolling circle amplification. Nat Genet 19:225-232

Luo J, Bergstrom DE, Barany F (1996) Improving the fidelity of thermos thermophilus DNA ligase. Nucleic Acids Res 24:3071-3078

Mari J, Bonami JR, Lightner DV (1993) Partial cloning of the genome of infectious hypodermal and hematopoietic necrosis virus, an unusual parvovirus pathogenic for penaeid shrimps: diagnosis of the disease using a specific probe. J Gen Virol 74:2637-2643

Mead DA, McClary JA, Luckey JA, Kostichka AJ, Witney FR, Smith LM (1991) Bst DNA polymerase permits rapid sequence analysis from nanogram amounts of template. Biotechniques 11:76-87

Nilsson M, Malmgren H, Samiotaki M, Kwiatkowski M, Chowdhary BP, Landegren U (1994) Padlock probes: circularizing oligonucleotides for localized DNA detection. Science 265:2085-2088

Nilsson M, Barbany G, Antson DO, Gertow K, Landegren U (2000) Enhanced detection and distinction of RNA by enzymatic probe ligation. Nat Biotechnol 18:791-793

Nilsson M, Antson DO, Barbany G, Landegren U (2001) RNAtemplated DNA ligation for transcript analysis. Nucleic Acids Res 29:578-581

Poulos BT, Nunan L, Mari J, Swider J, Lightner DV (1995) Use of the polymerase chain reaction to detect viral infections in penaeid shrimp. In: Browdy CL, Hopkins JS (eds) Swimming through troubled water. Proc Spec Sess Shrimp Farming, Aquaculture '95. World Aquaculture Society, Baton Rouge, LA, p 238-239

Schweitzer B, Wiltshire S, Lambert J, O'Malley S and 5 others (2000) Inaugural article: immunoassays with rolling circle DNA amplification: a versatile platform for ultrasensitive antigen detection. Proc Natl Acad Sci USA 97: 10113-10119

Shike H, Dhar AK, Burns JC, Shimizu C, Jousset FX, Klimpel KR, Bergoin M (2000) Infectious hypodermal and hematopoietic necrosis virus of shrimps is related to mosquito Brevidensoviruses. Virology 277:167-177

Tang KF, Lightner DV (2001) Detection and quantification of infectious hypodermal and hematopoietic necrosis virus in penaeid shrimp by real-time PCR. Dis Aquat Org 44: $79-85$

Tang KF, Lightner DV (2002) Low sequence variation among isolates of infectious hypodermal and hematopoietic necrosis virus (IHHNV) originating from Hawaii and the Americas. Dis Aquat Org 49:93-97

Thomas D, Nardone G, Randall S (1999) Amplification of padlock probes for DNA diagnostics by cascade rolling circle amplification or the polymerase chain reaction. Arch Pathol Lab Med 123:1170-1176 
Tong J, Cao W, Barany F (1999) Biochemical properties of a high fidelity DNA ligase from thermos species AK16D. Nucleic Acids Res 27:788-794

Tyagi S, Landegren U, Tazi M, Lizardi PM, Kramer FR (1996) Extremely sensitive, background-free gene detection using binary probes and beta replicase. Proc Natl Acad Sci USA 93:5395-5400

Varadaraj K, Skinner DM (1994) Denaturants or cosolvents improve the specificity of PCR amplification of a $\mathrm{G}+\mathrm{C}$ rich DNA using generally engineered DNA polymerases. Gene 140:1-5

Wiltshire S, O'Malley S, Lambert J, Kukanskis K, Edgar D,

Editorial responsibility: Timothy Flegel,

Bangkok, Thailand
Kingsmore SF, Schweitzer B (2000) Detection of multiple allergen-specific IgEs on microarrays by immunoassay with rolling circle amplification. Clin Chem 46:1990-1993

Zhang DY, Brandwein M, Hsuih TC, Li H (1998) Amplification of target-specific, ligation-dependent circular probe. Gene 211:277-285

Zhang DY, Brandwein M, Hsuih T, Li HB (2001a) Ramification amplification: a novel isothermal DNA amplification method. Mol Diagn 6:141-150

Zhang DY, Zhang W, Li X, Konomi Y (2001b) Detection of rare DNA targets by isothermal ramification amplification. Gene 274:209-216

Submitted: April 19, 2006; Accepted: August 1, 2006 Proofs received from author(s): November 29, 2006 